\title{
Entrepreneurship Education at Indian Industrial Training Institutes - A Case Study of the Prescribed, Adopted and Enacted Curriculum in and around Bangalore
}

\author{
Lea Zenner*1, Kothandaraman Kumar², and Matthias Pilz ${ }^{1}$ \\ ${ }^{1}$ Chair of Business and Economic Education and Training, University of Cologne, \\ Herbert-Lewin-Strasse 2, 50931 Cologne, Germany \\ ${ }^{2}$ Apeejay Surrendra Chair Professor of Family Business and Entrepreneurship, Indian Institute \\ of Management Bangalore Bannerghatta Road, Bengaluru, India
}

Received: 14.11.2016; Accepted: 31.03.2017; Published: 26.04.2017

\begin{abstract}
On the one hand, India is a growing economy that needs skilled labour, self-employed entrepreneurs and employees to tackle its economic and social challenges. On the other hand, India faces high unemployment rates, especially among young people. Graduates from industrial training institutes (ITIs) in particular are often facing difficulties in pursuing self-employment. Entrepreneurship education is an essential element in preparing young people for self-employment. This paper analyses how and to what extent entrepreneurship education has been conceived and implemented in vocational schools in and around Bangalore to face these challenges. Methodologically the authors use a three-step approach following the theories of a 'prescribed', 'adopted' or 'enacted' curriculum. Qualitative interviews are used for the analysis of the adopted and enacted curriculum. The authors conclude that whereas the prescribed curriculum includes several elements of entrepreneurship education and teacher's understanding is in line with the prescription, the understanding is seldom translated into input in the day-to-day teaching. The plausible reasons for this gap are discussed in this paper.
\end{abstract}

Keywords: VET, Vocational Education and Training, Entrepreneurship Education, India, Prescribed Curriculum, Enacted Curriculum, Industrial Training Centers, Industrial Training Institutes

\footnotetext{
*Corresponding author: matthias.pilz@uni-koeln.de
}

ISSN: 2197-8646

http://www.ijrvet.net 


\section{Introduction}

With a population of over 1.2 billion, India is the world's second most populous country after China, and its economy is growing at between 4 and $10 \%$ per year. A growing economy needs skilled labour, both self-employed entrepreneurs and employees, as the Indian government itself has acknowledged: "[The initiatives] Make in India and Skill India are complementary to each other" (Government of India [GoI], 2015, p. 25), because a more educated workforce is generally more productive (Palmer, Wedgewood, Hayman, King, \& Thin, 2007). Vocational training is crucial to developing employees' skills outside the academic environment and is most commonly provided at state-run Industrial Training Institute (ITIs) through the Craftsmen Training Scheme (CTS) (Rao, Sahoo, \& Gosh, 2014b).

Most individuals completing training at an ITI find it very difficult to make the transition to the labour market, and many face unemployment despite their qualifications (Rao, Joshi, Mathur, \& Sahoo, 2014a; World Bank, 2008). Yet at the same time, Indian employers find it harder to fill vacancies than their counterparts in many other countries (Federation of Indian Chambers of Commerce \& Industry [FICCI], 2012). Interestingly, only a minority of those completing vocational training actively seek self-employment as an alternative means of earning their living (World Bank, 2008).

Employers often blame this mismatch on the poor quality of those completing ITI training courses. They complain that these ITI trainees lack technical skills, practical skills and, particularly, vital soft skills, such as team-working and communication skills (Rao et al., 2014a). Employers also find that this group is inadequately prepared to run a business: they have not been trained as multi-skilled workers and lack exposure to the commercial skills that are required to perform as business persons (Kumar, 2016; World Bank, 2008).

To tackle the quantitative and qualitative problems in its vocational training provision, the Indian government adopted in 2009 a National Policy on Skill Development (GoI, 2009), which set the goal of training 500 million individuals by 2022 . As well as producing greater numbers of skilled workers, however, the policy also aimed to address the quality of training courses, through the equipping of Indian nationals with the knowledge, expertise and skills required for the labour market and/or for running their own business.

In 2015, this policy was updated as the National Policy on Skill Development and Entrepreneurship (GoI, 2015), which regards the promotion of entrepreneurship as a crucial tool in the fight against poverty. Entrepreneurship education is the first of the nine strategies that make up the Entrepreneurship Framework: "Educate and equip potential and early stage entrepreneurship across India" (GoI, 2015, p. 35). This strategy provides for an entrepreneurship education curriculum to be developed in collaboration with experts and made available across the country, free of cost, for all Indian citizens, either face-to-face or online (GoI, 2015). Beside the Entrepreneurship Framework, there already exist the core 'employability skills' curriculum at the ITIs covering entrepreneurship education (GoI, 2011, 2014b). The introduction of the 'employability skills' curriculum takes the 'delivery context' (Palmer et al., 2007, p. 73) into consideration, aiming 
firstly to enhance the quality of the ITI education as well as the graduates, and secondly to facilitate the school-to-work transition of the latter. Because this curriculum has been implemented only recently, our research focuses on the quality of the input (curriculum design and teachers' level of education and training) and process (teaching methodologies) rather than on the output (Tara, Kumar, \& Pilz, 2016). In this paper we use a three step approach analysing the prescribed, adopted and enacted curriculum (see in detail section 3). Therefore, we investigate firstly the extent to which entrepreneurship education is currently embedded in ITI curricula, secondly the teacher's understanding of entrepreneurship education and their interpretation of the curriculum and thirdly how it is actually delivered in day-to-day teaching. We illustrate the opportunities and difficulties involved, including the issues raised in the implementation of the new curriculum. However, we first outline the research context and our methodological approach before discussing the findings.

\section{Research Context}

To elaborate the research context, we define, in this section, what we mean by 'entrepreneurship education', provide an overview of the Indian vocational education and training (VET) context, and highlight the importance of entrepreneurship education in this context.

\subsection{Defining 'Entrepreneurship Education'}

Clearly defining the concept of 'entrepreneurship education' is crucial to any investigation of how it is embedded in the curriculum and delivered. The international literature makes a distinction between a 'narrow' and a 'wide' definition of entrepreneurship (Lackéus, 2015; Metcalfe, 2004; Stevenson \& Jarillo, 1990).

The 'narrow' definition depicts the goal of entrepreneurship education as 'becoming an entrepreneur', with emphasis on preparation for setting up a business. This narrow definition embraces primarily theoretical content relating to entrepreneurship, the identification of opportunities, business development, self-employment, venture creation, and growth (Gartner, 1990; Lackéus, 2015).

In contrast, the goal of the 'wide' definition is 'becoming entrepreneurial' (Lackéus, 2015). The main focus of this approach is learning the skills for successful entrepreneurship - that is, developing as an individual who thinks and acts entrepreneurially in any professional situation, not just in the context of setting up a business (Stevenson \& Jarillo, 1990). Thus acting entrepreneurially is something that employed individuals can also do (Shane \& Venkataraman, 2000). Personal development, creativity, self-reliance, initiative and an action orientation form the core elements of this wide definition of entrepreneurship education (Lackéus, 2015). Fisher, Graham and Compeau (2008) define a framework for analysing learning outcomes in entrepreneurship education, which also serves as the basis for developing and continuously improving entrepreneurship education. Our definition of entrepreneurship education draws on this framework in dividing the subject-matter into three domains: knowledge, attitudes and skills. This division 
is common in the literature (EURYDICE, 2012; Heinonen \& Poikkijoki, 2006; Lackéus, 2015). It is based on a 'wide' definition and embodies the idea that the essence of entrepreneurship education is to develop not only entrepreneurial knowledge but also entrepreneurial skills and attitudes. Table 1 indicates our understanding of entrepreneurial competencies based on the 'wide' definition, which forms the basis for the further analysis of the prescribed and enacted curricula.

Table 1: Entrepreneurial competencies (authors' own compilation, drawing on Fisher et al., 2008, p. 320; Lackéus, 2015, p. 13).

\begin{tabular}{|c|c|c|}
\hline Domain & Sub-Domain & Definition \\
\hline \multirow[t]{3}{*}{ Knowledge } & $\begin{array}{l}\text { K1) Knowledge of ca- } \\
\text { reer opportunities and } \\
\text { of the world of work }\end{array}$ & $\begin{array}{l}\text { Knowledge of the world of work, of differ- } \\
\text { ent types of employment, of what being an } \\
\text { entrepreneur means, defining the individual's } \\
\text { role in the world of work and applying it per- } \\
\text { sonally, developing the individual's awareness } \\
\text { of his or her own scope and limitations }\end{array}$ \\
\hline & $\begin{array}{l}\text { K2) Business and fi- } \\
\text { nancial knowledge }\end{array}$ & $\begin{array}{l}\text { Knowledge of concepts and processes con- } \\
\text { nected with entrepreneurship }\end{array}$ \\
\hline & $\begin{array}{l}\text { K3) Knowledge of busi- } \\
\text { ness organisation and } \\
\text { processes }\end{array}$ & $\begin{array}{l}\text { Knowledge of the business environment, set- } \\
\text { ting up a business, how businesses operate } \\
\text { and fair trade }\end{array}$ \\
\hline \multirow[t]{6}{*}{ Attitudes } & A1) Ability to reflect & $\begin{array}{l}\text { Self-assessment of strengths and weaknesses, } \\
\text { assessment of risks, reflection on the indi- } \\
\text { vidual's own behaviour, and critical thinking } \\
\text { and questioning }\end{array}$ \\
\hline & $\begin{array}{l}\text { A2) Entrepreneurial } \\
\text { identity }\end{array}$ & $\begin{array}{l}\text { Entrepreneurship values, awareness of re- } \\
\text { sponsible and social business management }\end{array}$ \\
\hline & A3) Self-efficacy & Self-awareness and self-confidence \\
\hline & A4) Pro-activeness & Creativity: innovation and imaginativeness \\
\hline & $\begin{array}{l}\text { A5) Entrepreneurial } \\
\text { passion }\end{array}$ & Initiative \\
\hline & A6) Perseverance & Problem-solving \\
\hline \multirow[t]{4}{*}{ Skills } & S1) Opportunity skills & $\begin{array}{l}\text { Practical research into opportunities for en- } \\
\text { trepreneurship }\end{array}$ \\
\hline & S2) Strategic skills & Planning skills, project management \\
\hline & S3) Resource skills & Drawing up and implementing business plans \\
\hline & S4) Interpersonal skills & $\begin{array}{l}\text { Communication skills, successful presenta- } \\
\text { tion and negotiation, team-working skills, } \\
\text { networking }\end{array}$ \\
\hline
\end{tabular}




\subsection{An Overview of Vocational Education and Training in India}

India's education system comprises an elementary stage, lasting for eight years, followed by a two-year secondary stage and a higher secondary stage, also lasting for two years. Young people have the opportunity to leave general education for the labour market or a programme of vocational training at a number of points. The 2009 Right to Education Act introduced compulsory free schooling for children between the ages of 6 and 14, but around $40 \%$ of students drop out before they have completed their elementary education (GoI, 2014a, 2014c). However, eight years' basic education is the minimum requirement for entry into a formal programme of vocational training (Mehrotra, Kalaiyarasan, Kumra, \& Raman, 2015, p. 17). Those students dropping out before completing elementary education usually enter the informal sector, which constitutes around $93 \%$ of total employment (King, 2007).

Most formal vocational training takes place in full-time vocational schools, state-run ITIs or private Industrial Training Centers (ITCs). Trainees are enrolled in the CTS, which teaches basic, practical, occupational skills, primarily in the craft or industrial sector. The aim is to prepare those who complete the CTS for self-employment or as semi-skilled workers in an employed context. Those passing the final examination are awarded a nationally recognised certificate (Rao et al., 2014a, 2014b).

The CTS is delivered through a standard curriculum prescribed by the National Council for Vocational Training (NCVT). The curriculum covers 133 trades, comprising 70 engineering and 63 non-engineering trades. The courses vary from six months to three years. Students with varying levels of entry level education $8^{\text {th }}, 10^{\text {th }}$ or $12^{\text {th }}$ grade are admitted to the course depending on the type of trade (GoI, 2014b).

National level institutions, such as the Central Staff Training and Research Institute (CSTARI) at Kolkata and the National Instructional Media Institute (NIMI) at Chennai, help in the development of the curriculum through research, development of the pedagogy and course materials. The prescribed qualification for teachers is either a diploma or a graduate degree with a minimum level of experience. The selection process for teachers is conducted at the state level. The selected teachers (craft instructors) are trained by one of the seven dedicated Central Training Institutes. Those trainees who successfully clear an All India Trade Test are awarded a National Trade Certificate by NCVT (World Bank, 2008).

In general, the vocational training provided by ITIs is seen to be falling short when it comes to the skills required for performing on the job. Specifically, the employers lament the lack of team working and communication skills amongst the craftsmen trained in the ITIs. Nor are these trained craftsmen seen as being well prepared for self-employment. Specifically, they do not seem to have received training as multi-skilled workers and they also lack exposure to commercial skills, so important for performing as business persons (World Bank, 2008).

\subsection{Importance of Entrepreneurship Education in the Indian Context}

VET in India has consistently been seen as deficient in terms of producing desirable employment outcomes for trained craftsmen. Prior studies have indicated that even after three years from graduation, $60 \%$ of the graduates are still not employed (World 
Bank, 2008). Furthermore, the proportion of ITI graduates who became either selfemployed or employers, thus entering the informal sector, was just over $10 \%$ in the case of government-owned ITIs and only around $5 \%$ in the case of privately-run ITCs (World Bank, 2008). A common reason for this low level of employment in both the organized sector and self-employment as part of the informal sector is attributed to the lack of well-rounded training beyond the occupational skill to include multiple workrelated skills such as team working, communication and problem solving (World Bank, 2008). Recognizing this deficiency, the skill development policy of the GoI has been updated in 2015 and has been aptly titled the 'National Policy on Skill Development and Entrepreneurship 2015'. Noting that India has one of the lowest rates of companies registered per 1000 working-age persons amongst the G20 countries in 2011, this policy emphasizes the need to "bring the world of education and training closer to the world of work" and emphasises the importance of creating entrepreneurial opportunities through an enabling eco-system that includes appropriate education and training (GoI, 2015, p. 10).

\section{Research Question and Current State of Research in the Field}

The objective of this paper is to portray the status quo of entrepreneurship education within vocational education in India. We show how, and to what extent, entrepreneurship is taught in the ITIs in order to identify potential for optimisation. We address the following three research questions:

A How is entrepreneurship education embedded in the curricula (the prescribed curriculum)?

B How do teachers interpret entrepreneurship education (the adopted curriculum)?

C How, and to what extent, is entrepreneurship education delivered by teachers (the enacted curriculum)?

This process drew on literature relating to the 'prescribed' and 'enacted' curriculum (Bloomer, 1997; Edwards, Miller, \& Priestley, 2009). Teachers' knowledge and understanding of the intervention are regarded as an important element in the process of curriculum implementation. For this reason the approach was extended to the 'adopted' curriculum which draws on research on curriculum implementation taking teacher's interpretation, hence their adoption of the curriculum for their everyday teaching, into consideration (Fullan \& Pomfret, 1977).

The literature review showed no evidence of any research on the topic of 'prescribed', 'adopted' and 'enacted' curricula in the context of entrepreneurship education in India. While several studies focus on the Indian VET system and its challenges (e.g. Mehrotra, 2014; Pilz, 2016), broader studies addressing curricular questions and teaching in ITIs are rare.

Mehrotra et al. (2015) have focused on the output of ITIs, researching companies about staff perceptions of ITI leavers. They found that company personnel consider ITI 
graduates lack "application-oriented knowledge and problem-solving skills" (p. 265) both elements of the wide definition of entrepreneurship education (section 2.1).

A similar methodological approach was taken by Pilz, Krisanthan, Michalik, Zenner and Li (2016). Their study compared the 'prescribed' and 'enacted' curricula in the area of pre-vocational education in secondary schools between four different countries, including India. Overall, Indian teachers regarded the prescribed curriculum as completely taught. Yet the emphasis was placed especially on knowledge, with less on skills or attitudes. Most teachers regarded preparation for students' final exams as highly important. Tara et al. (2016) confirm these findings to be valid in the case of ITIs.

Whereas the focus in the study of Pilz et al. (2016) was on both the curriculum design and the implementation, the focus in this paper is on the teachers' interpretation and implementation (research questions B and C), taking the results of the curriculum analysis (research question A) as a starting point. Our analysis of the prescribed and enacted curriculum, based on the wide and internationally-accepted understanding of entrepreneurship education (section 2.1) against the backdrop of the issues relating to the entrepreneurial and the personal independence of ITI graduates (section 2.2), is of relevance to transitions to employment in the Indian context. Research question A was tackled by curriculum analysis of the 'employability skills' curriculum (GoI, 2014b, 2011) while the answers of question $B$ and $C$ are based on semi-standardized qualitative interviews with ITI teachers at eight different ITIs in and around Bangalore. In a diverse country like India, it is not possible to generalise the findings of one area for the whole country, which in any case we do not intend to do in this paper. However, the area of Bangalore serves as a valuable test-bed for our research. Bangalore is an area located in the heart of India covering rural as well as urban areas. Furthermore it shows a crosssection of the cultures represented in India. Bangalore is also considered to have the most advanced entrepreneurial eco-system in India, often inviting comparisons with Silicon Valley. Hence, it is reasonable to expect the implementation of the recently mandated entrepreneurship curriculum in the ITIs in Bangalore to be a forerunner in India- both in terms of speed and quality of implementation (Herrmann, Gauthier, Holtschke, Berman, \& Marmer, 2015).

The details on our methodological approach are described in direct relation to the findings (sections 4 and 5).

\section{Details of Study Design and Analysis of the Prescribed Curriculum}

Research question A concerning the prescribed curriculum was addressed by means of a theory-driven curriculum analysis. This review was focused on the 'employability skills' curriculum (GoI, 2014b, 2011), which includes elements of entrepreneurship education. This curriculum was first introduced in 2011 and updated in 2014 (GoI, 2014b). We could not assume that all vocational schools have yet implemented the new curriculum, so we included both in our curricular analysis. To reduce the risk of misinterpretation, we also included in our analysis the teaching materials developed by the NIMI in Chennai and officially made available to teaching staff (Kumar, 2016). The approach underpin- 
ning our curriculum analysis was qualitative content analysis. The category system used represents a synthesis of induction and deduction (Schreier, 2012) and draws on our understanding of entrepreneurship education (section 2.1). The emphasis of the curriculum analysis is not on quantifying the codings (in contrast to former studies, e.g. Berger et al., 2012; Pilz et al., 2016), but rather to show which elements of knowledge, attitudes and skills are prescribed in the curriculum and which definition (wide or narrow) is followed. The analysis then forms the basis for the interviews, identifying similarities or differences in the intention of the prescribed curriculum and the enacted curriculum by the teachers. We used the framework in Table 1 (section 2.1) to derive codes and subcodes to underpin the curriculum analysis. The theoretical category system was used for a pilot study, the findings of which gave rise to further codes (Schreier, 2012).

\subsection{Findings of the Curriculum Analysis}

The 'employability skills' curricula divide into five or eight modules (2011 and 2014 curricula respectively). 'Entrepreneurship' is explicitly included as one module in both curricula and is taught for 20 hours in the 2011 curriculum and for 10 hours in the 2014 curriculum. Further modules are among others 'communication skills', 'English language skills' or 'environment education'. The sub-sections, which are divided into thematic areas, describe the knowledge, skills and attitudes to be acquired. In some cases, these are supplemented with teaching recommendations. The teaching materials are compiled in Instructional Media Packages (IMPs) that include the theoretical content, practical exercises, tests, and a CD-ROM with listening exercises. These are closely tailored to the 2011 curriculum. Some of the entrepreneurship education learning outcomes are integrated into other modules in the 'employability skills' curriculum. Consequently, we have analysed not just the 'entrepreneurship' module but also the other modules in this curriculum. Codes were derived primarily from the modules on 'communication skills' and 'English language skills'.

\section{Knowledge}

Both, in the curricula and in the teaching materials, the emphasis in the 'entrepreneurship' module is on teaching knowledge. In total, eight of the eleven categories were identified in at least one 'employability skills' curriculum or in teaching materials. Seven out of those eight identified categories were recognised in the 'entrepreneurship' module.

Table 2 presents the codes identified. 'Yes' means teaching input in the respective category has been identified. Dimensions not identified in the analysed curricula and teaching materials are highlighted with bold letters. 
Table 2: Codes identified for the 'knowledge' dimension

\begin{tabular}{|c|c|c|c|c|}
\hline & Knowledge & $\begin{array}{l}\text { Curriculum } \\
2011\end{array}$ & $\begin{array}{l}\text { Curriculum } \\
2014\end{array}$ & $\begin{array}{l}\text { Teaching } \\
\text { Materials }\end{array}$ \\
\hline K1.1: & Knowledge of the world of work & yes & yes & no \\
\hline K1.2: & $\begin{array}{l}\text { Knowledge of different types of } \\
\text { employment }\end{array}$ & no & no & no \\
\hline K1.3: & $\begin{array}{l}\text { Knowing what being an en- } \\
\text { trepreneur means }\end{array}$ & yes & yes & yes \\
\hline K1.4: & $\begin{array}{l}\text { Defining the individual's role in the } \\
\text { world of work and applying it per- } \\
\text { sonally }\end{array}$ & yes & yes & yes \\
\hline K1.5: & $\begin{array}{l}\text { Developing the individual's } \\
\text { awareness of his or her own } \\
\text { scope and limitations }\end{array}$ & no & no & no \\
\hline $\mathrm{K} 2.1$ & $\begin{array}{l}\text { Knowledge of entrepreneurial con- } \\
\text { cepts }\end{array}$ & no & no & yes \\
\hline $\mathrm{K} 2.2$ : & $\begin{array}{l}\text { Knowledge of processes connected } \\
\text { with entrepreneurship }\end{array}$ & yes & yes & yes \\
\hline K3.1: & $\begin{array}{l}\text { Knowledge of the business environ- } \\
\text { ment }\end{array}$ & yes & yes & yes \\
\hline K3.2: & Knowledge of setting up a business & no & no & yes \\
\hline K3.3: & $\begin{array}{l}\text { Knowledge of how businesses oper- } \\
\text { ate }\end{array}$ & yes & yes & yes \\
\hline K3.4: & Knowledge of fair trade & no & no & no \\
\hline
\end{tabular}

Both curricula provide for teaching on knowledge of the world of work, but content related to this area could not be identified in the teaching materials.

The curricula also include topics to develop understanding of what it means to be an entrepreneur. The curricula include content such as entrepreneurial values, attitudes and motives, the characteristics of a successful entrepreneur and a successful business, the importance of skills, the identification and development of entrepreneurial competence and networking, and entrepreneurial culture. They do not specify whether this involves a purely theoretical consideration of entrepreneurial attitudes, characteristics and skills or whether students actually develop these elements. Scrutiny of the teaching materials indicates, however, that the approach is purely theoretical.

The curricula also attempt to tackle the requirements for students to be able to define and develop their own role in the world of work by including career-planning as a learning 
outcome. It is also clear from the teaching materials that students are required to read job descriptions, practise applying for these jobs, and set goals for their own careerplanning based on self-assessment of their own strengths and weaknesses.

With regard to the processes linked to entrepreneurship, the curricula focus on the needs and scope of entrepreneurial self-employment along with forms of support (particularly financial) and applicable frameworks. They also specify content related to the business environment, including customers, markets, and health and safety. The curricula additionally specify learning outcomes related to how businesses operate, which may include such areas as marketing methods and various aspects of quality and management systems. Scrutiny of the teaching materials also revealed content in relation to business concepts and setting up a business. This includes the distinction between small, medium-sized and large businesses, for example, or between companies in the manufacturing and services sectors. Further input is geared to equipping students to draw up a business plan or to prepare and present a project report. The project report component also involves exercises that require students to apply their knowledge in practice.

\section{Attitudes}

Content indicating learning in the 'attitude' domain was identified for seven out of ten codes. Here they were mainly identified in the 'entrepreneurship', 'environment' and 'communication skills' modules (Table 3).

Table 3: Codes identified for the 'attitudes' domain

\begin{tabular}{lllll}
\hline & Attitudes & \multicolumn{2}{c}{$\begin{array}{c}\text { Curriculum } \\
\text { Curriculum }\end{array}$} & $\begin{array}{l}\text { Teaching } \\
\text { Materials }\end{array}$ \\
\hline A1.1: & $\begin{array}{l}\text { Self-assessment of strengths and } \\
\text { weaknesses }\end{array}$ & yes & no & yes \\
\hline A1.2: & Assessment of risks & yes & yes & no \\
\hline A1.3: & $\begin{array}{l}\text { Reflection on the individual's } \\
\text { own behaviour }\end{array}$ & no & no & no \\
\hline A1.4: & $\begin{array}{l}\text { Critical thinking and question- } \\
\text { ing }\end{array}$ & no & no & no \\
\hline A2.1: & Entrepreneurship values & yes & yes & yes \\
\hline A2.2 & $\begin{array}{l}\text { Awareness of responsible and social } \\
\text { business management }\end{array}$ & no & yes & no \\
\hline A3: & Self-awareness and self- confidence & yes & yes & yes \\
\hline A4: & $\begin{array}{l}\text { Creativity: innovation and imagina- } \\
\text { tiveness }\end{array}$ & yes & no & yes \\
\hline A5: & Initiative & no & no & no \\
\hline A:6 & Problem-solving skills & no & yes & yes \\
\hline
\end{tabular}


The 'entrepreneurship' module, for example, describes self-analysis as a learning outcome, suggesting that self-assessment of their own strengths and weaknesses are part of the teaching that students receive. Scrutiny of the teaching materials relating to this area reveals exercises tailored to this learning outcome. Students are presented with the key characteristics of entrepreneurs and then reflect on whether they see themselves as having strengths or weaknesses in these areas. These exercises are designed to pinpoint areas in which students have weaknesses so that they can work to overcome them. Overall, it is clear that while teaching input relating to self-assessment skills is evident, students are not really being equipped to develop these skills successfully.

We also identified curriculum content related to awareness of general ethical values. Relevant teaching materials cover areas including reliability, respect, responsibility, awareness of the law, fairness, environmental protection, and electoral systems.

Moreover, both the 2011 and the 2014 curricula describe 'motivational training' as part of the teaching programme. This covers, for example, the characteristics that contribute to success, the importance of a positive attitude, self-awareness, ethics and values, self-motivational methods, goal-setting and career-planning. Research into motivation shows that to be motivated, students need to appreciate the relationship between their own efforts and achievement of their goals, to set ambitious goals for themselves, and to pursue them determinedly and to their own standards (e.g. Bransford, Brown, \& Cocking, 2000). Support with goal-setting and career-planning gives a particular boost to students' motivation, enabling them to experience self-effectiveness and increasing their self-awareness (Jiang \& Kleitman, 2015). Self-awareness is, therefore, a further motivational factor.

The 2014 curriculum identifies problem-solving skills as a learning outcome. The teaching materials include exercises that involve students in analysing a range of problems and devising possible solutions. Theoretical approaches to problem-solving processes form the basis for this.

\section{Skills}

We were able to identify six of the eight entrepreneurial skills in one of the two curricula or in the teaching materials for the 'entrepreneurship' and 'communications skills' modules. Table 4 below depicts the codes identified.

In the 'communication skills' module of the 2011 curriculum, time-management is included under the heading of planning skills, and teaching input promotes development of a range of tools to enable students to plan and organise their working day efficiently. It also incorporates project management skills, including project design, feasibility and cost-effectiveness.

It also emerges from the teaching documentation that the students are required to develop their own entrepreneurial concept for a product that they have thought of.

The 2011 curriculum focuses on developing wide-ranging communication skills, teaching both basic knowledge about communications and techniques for dealing with barriers to communication and nervousness and for conducting interviews. The content and learning outcomes for non-verbal communication, manners, etiquette and dress codes are included under 'successful presentation'. 
Table 4: Codes identified for the 'skills' domain

\begin{tabular}{|c|c|c|c|c|}
\hline & Skills & $\begin{array}{l}\text { Curriculum } \\
2011\end{array}$ & $\begin{array}{l}\text { Curriculum } \\
2014\end{array}$ & $\begin{array}{l}\text { Teaching } \\
\text { Materials }\end{array}$ \\
\hline S1: & $\begin{array}{l}\text { Practical research into oppor- } \\
\text { tunities for entrepreneurship }\end{array}$ & no & no & no \\
\hline S2.1: & Planning skills & yes & yes & yes \\
\hline S2.2: & Project management & yes & yes & yes \\
\hline S3: & $\begin{array}{l}\text { Drawing up and implementing } \\
\text { business plans }\end{array}$ & no & no & no \\
\hline S4.1: & Communication skills & yes & yes & yes \\
\hline $\mathrm{S} 4.2$ & $\begin{array}{l}\text { Successful presentation and negoti- } \\
\text { ation }\end{array}$ & yes & yes & yes \\
\hline $\mathrm{S} 4.3$ & Team-working skills & no & no & yes \\
\hline S4.4 & Networking & yes & no & no \\
\hline
\end{tabular}

The 'entrepreneurship' module also aims to equip students to develop their networking skills. However, this learning outcome is not explicitly formulated in the teaching materials and was deduced from the suggestions for group-work contained in the materials.

The 2014 curriculum also tackles all of these skills areas with the exception of networking. The major difference between the two curricula is that the 2011 curriculum is substantially more detailed; some parts of the 2014 curriculum have been pared down to such an extent that they offer virtually no in-depth information on individual areas, which has a negative impact on the clarity and comprehensibility of the curriculum. Without teaching documentation, it is very difficult to discern which thematic areas are relevant to teaching and in what depth and breadth they are tackled.

\subsection{Summary and Discussion of Findings of the Curriculum Analysis}

Overall, it can be concluded that the 'knowledge' domain codings predominate in the 'entrepreneurship' module. Analysing other modules from the 'employability skills' curriculum produced a non-significant difference in the codings for the three dimensions in eight 'knowledge' categories and seven each of the 'attitudes' and 'skills' categories.

Considering solely the learning outcomes described in the 'entrepreneurship' module illustrates that these outcomes focus predominantly on the skills needed to set up and run a business. The module is, therefore, based on the narrow definition of entrepreneurship education. This is reflected also in the skills, attitudes and characteristics of entrepreneurs described in the teaching materials, which focus overwhelmingly on the skills that entrepreneurs need to set up and manage businesses, set ambitious goals and work towards them, their willingness to take risk, creativity and optimism, how entrepreneurs 
can solve problems, and how they are motivated by achievement and success.

The wider understanding of entrepreneurship education that underpins this study also covers elements of personal independence as well as professional autonomy. In most cases, these elements are integrated into other modules in the 'employability skills' curriculum, with 'employability' understood fundamentally as 'readiness for work' (Brewer, 2013). The aim of the 'employability skills' curriculum is, therefore, to prepare students for work (personal independence). For example, most of the attitudes and skills that form part of a broadly defined 'entrepreneurship education' are contained in the 'communication skills' module. Not all attitudes and skills could be coded, but it was possible to identify approaches to a broad understanding of entrepreneurship education under the concept of 'employability skills'. The 'entrepreneurship' module is a part-aspect of this basic readiness for work, and module content aims specifically at entrepreneurial independence.

\section{Details of Study Design and Analysis of the Adopted and Enacted Curriculum}

Research questions B ('How do teachers interpret entrepreneurship education?') and C ('How, and to what extent, is entrepreneurship education delivered by teachers?') relate to the enacted curriculum and were addressed through qualitative interviews. In the Indian context it is complicated to conduct classroom observations, because permissions are difficult to receive. Qualitative interviews instead of observations were therefore chosen as the method to address these two research questions. Even though this method shows weaknesses (for example, the subjective view of the teachers), it is considered the most appropriate way to capture teachers' understandings of entrepreneurship education and their interpretations of curriculum (Wragg, 2012; Fullan \& Pomfret, 1977). Furthermore validity checks using the observation method showed that questioning teachers is quite effective at measuring degree of implementation (Fullan \& Pomfret, 1977). Because of the small number of interviews with the teachers (section 3), it is not possible to generalise our findings, and we do not intend to do so. We also did not identify any trends between the answers and the age, sex and state of experience of the teachers.

Teachers who teach the 'employability skills' curriculum at ITIs were interviewed, because they are the central persons who interpret and then deliver the prescribed curricula in their everyday teaching. In total eight teachers teaching the 'employability skills' curriculum at eight different ITIs in and around Bangalore were interviewed. ITIs were selected by partner institutions in India and teachers were named by ITIs. However, given the context of Indian culture, hierarchy and complex administrative processes, the choice of respondents (ITIs) was dictated more by accessibility than an ex-ante list of desirable respondents. However, an ex-post analysis of respondents (both the institutes and teachers) shows diversity along a variety of different characteristics:

- ITIs are located in urban as well as rural areas (T5, T6 and T7).

- The size of the ITIs varies between small ITIs (e.g.: 53 students and 6 faculties (T5)) up to big ITIs (e.g.: around 1000 students and a faculty of 73 trainers (T8)). 
- The qualification of the teachers most teachers have a Bachelor of Arts, Science or Engineering (T1, T2, T3, T7, T8), one teacher has National training certificate (T5), one teacher has a Diploma (T4) and one teacher has even a Master of Arts (T6).

- The entrepreneurial experience (running or working in a business) of the teachers (e.g. from no experience at all $(\mathrm{T} 4, \mathrm{~T} 6)$ to one year of work experience in a business (T7) and up to 20 years of work experience in a business (T1). However, it is noteworthy that none of the teachers has any experience in running a business.

- The experience in teaching "employability skills" curriculum - e.g. from 2 month (T2) up to more than 20 years (T7, T6).

- Most ITIs collaborate with companies and receive formal (T1, T3, T5, T7 and T8) or informal training on their feedback.

A semi-standardised questionnaire was developed for these interviews, based on the definition of entrepreneurship education (section 2.1) and on the finding of the curriculum analysis (section 4). In the first part of the interview teachers were asked about their understanding of entrepreneurship education based on the analysis of the prescribed curriculum. In the second part of the interview teachers were asked how and to what extent they actually teach entrepreneurship education in the day-to-day teaching. The interviews were analysed using qualitative content analysis on the basis of a category system drawing on our understanding of entrepreneurship education and the results of the curriculum analysis (Schreier, 2012; Fullan \& Pomfret, 1977).

To compare the prescribed and enacted curricula, we first established which curriculum the teachers were using. Five said they were using the 2014 curriculum and three the 2011 curriculum.

\subsection{Teachers' Understandings of Entrepreneurship Education (Adopted Curriculum)}

Research question B is aimed at investigating teachers' understanding of the concept of entrepreneurship education, since this understanding influences the way in which skills are developed through teaching (Fullan \& Pomfret, 1977). The question was also designed to identify potential discrepancies between the intentions behind the curricula and individual teachers' understanding. Teachers were, therefore, asked what they understood by entrepreneurial knowledge, attitudes and skills.

Their widely varying responses highlight the fact that they have different understandings both of entrepreneurial knowledge and of skills and attitudes. Five teachers reported that their approach to teaching entrepreneurial knowledge was to teach theoretical knowledge using the blackboard and tools such as presentations, role-play, group-work and case studies. These teachers described skills and attitudes as practical knowledge that the students could acquire through company visits or by attending talks on best practice by successful entrepreneurs: "Skills are about getting hands-on experience. So we show video clips about specific subjects and let them work with computers for ITtopics. Knowledge is only the information with blackboard and power point." (T3). 
One teacher also reported that he used 'hands-on experience' to teach skills, though he did not explain what this meant. There is a clear separation between these areas, then, and teachers believe that skills and attitudes are best acquired through doing.

With regard to entrepreneurial knowledge, teaching focused in all eight cases on setting up and running a business. Five teachers made it clear that their aim was to open up the range of career perspectives to trainees and to show them the benefits and success they could achieve through self-employment. They also demonstrate the personal financial success that entrepreneurship can bring as well as the social benefits, such as the creation of new jobs. In this context, one teacher told us: “... we do different projects and give them the chance to choose between getting more information about own business or working in a business." (T1).

Furthermore they reported the following with regard to their understanding of entrepreneurial knowledge:

- One teacher offers students the opportunity to obtain information about both career pathways and to develop their awareness of the opportunities open to them.

- For three teachers, however, the aim was also to equip students to continue to develop their skills and to shape their lives independently.

- Five teachers also reported that knowledge of sales and marketing was important for running a business.

- In some cases, however, they also provided information on sources of state and financial support, different types of business, financial and business processes, the awareness of quality, and knowledge of labour legislation.

- In two cases, respondents also referred to the importance of technical and professional knowledge.

The teachers' understanding of entrepreneurial knowledge therefore overlapped to a considerable extent with the content specified in the curricula. In fact, it even covered issues that also form part of other modules in the 'employability skills' area. What is surprising is that knowledge of setting up a business was mentioned by all teachers even though it does not feature in either curriculum and appears only in teaching materials: "Knowledge about starting an industry, types of industry, financial opportunities, marketing of goods, support by government."(T7).

However, this strengthens the argument that teachers take their main orientation from teaching materials. A broad and very diverse picture emerges of the entrepreneurial skills and attitudes that may be inferred from the interviewees' definitions, with a very wide range of examples being quoted. Teachers mentioned the following attitudes and skills that are reflected in the curricula:

- ability to reflect (e.g. "behaviour, good character, positive thinking, overcome their weaknesses and identify strengths" (T2))

- entrepreneurial identity (e.g. "quality statements, values of being an employer" (T1)) "leadership qualities" (T6), "attitudes to become a leader and to start a business" (T7)) 
- self-efficacy (e.g. "self-confidence" (T4))

- pro-activeness (e.g. "creativity and courage" (T9))

- entrepreneurial passion (e.g. "initiative" and "willingness to start an entrepreneurship or to got to industry" (T4), "risk-taking, independent mind of their own, don't want to be an employee" (T6), "motivation and initiative for quality" (T8))

- opportunity skills (e.g. "seeking jobs, profit making" (T4), "looking for opportunities" (T5))

- strategic skills (e.g. "foresight, future plans and the thinking of one's own profit as well as for others the society" (T8))

- resource skills (e.g. "fostering knowledge, market-, marketing and sales competencies" (T8))

- interpersonal skills (e.g. "life skills like communication ... acting in different situations and with many persons" (T2), "interacting with other people" (T6) "good communications skills" (T7))

This list includes attitudes and skills that also feature in the curriculum of one of the 'employability skills' modules - planning and project management skills and networking - as well as additional attitudes and skills, such as focus, independence, initiative, a positive attitude and profit-seeking. One teacher argued that entrepreneurial attitudes could not be taught: "You can't teach it, you must have it" (T1).

This reflects the range of statements made by interviewees when they were asked about differences in the teaching of knowledge, skills and attitudes. Three teachers reported that they did not teach entrepreneurial skills and attitudes, citing a lack of resources to do so: "We have no space for practical activities. We have only a rented building. The rooms are too small. We can't even use our CNC machine because of less space. Nobody can teach skills." (T6).

Overall, it may be concluded that respondents take a broad view of entrepreneurship: they cite the importance of content that goes beyond the narrow description contained in the 'entrepreneurship' module. They also see their students' development into independent and responsible individuals as part of their entrepreneurship education, mirroring the wide definition of the concept. Some teachers point to potential problems with teaching a more broadly-defined form of entrepreneurship education, however, and the next section outlines how this is achieved in day-to-day teaching.

\subsection{Delivering Entrepreneurship Education in Day-to-Day Teaching (Enacted Curriculum)}

After establishing the teachers' understandings of entrepreneurship education, we moved to the third research question - how it is delivered in day-to-day teaching. We asked teachers to indicate the extent from not taught at all to teach overarching - to which their teaching actually delivered the curriculum prescribed for entrepreneurship education. The curriculum analysis showed that the prescribed curriculum did not cover every 
entrepreneurial competency (section 2.1, table 1). Those competencies not identified in the prescribed curriculum were, therefore, left out in the analysis of the enacted curriculum. Interviewees were asked to assess their teaching input in each of the three domains.

\section{Knowledge}

Questions in the 'knowledge' domain focused on the three main categories 'knowledge of career opportunities and of the world of work' (K1), 'business and financial knowledge' (K2) and 'knowledge of business organisation and processes' (K3).

Teachers consider their teaching input in the area of 'knowledge of career opportunities and the world of work' overall as 'wide-ranging'. Just one teacher (T5) reported only limited input in this area. Most ITIs invite or visit companies to show possible career pathways: "We do company visits to create the awareness of the industry close to the ITI and show available job opportunities" (T3).

They considered teaching input somewhat higher in the area of 'knowledge of business organisation and processes', where the widest range of responses was also evident. Going into detail it became clear, that the focus in this area was more on the knowledge of business environment instead of setting up and running a business. While two teachers reported that they spent little, if any, time teaching the business environment, three said that they covered it in a wide-ranging way and three teachers mentioned that they covered it comprehensively: "We teach it in a wide-ranging way. We cover market, customer and safety issues" (T1). In contrast, the teaching input reported for "setting up and running a business' was low. Three teachers said they did not teach the area, two said that their input was limited and three responded that it was wide-ranging. One of the teachers reporting limited input in this area added: "We give only awareness for that since most students want to go for employment" (T9).

It seems that respondents do not attach great importance to developing knowledge in this area, since many students are not considering self-employment. The fact that teaching input here is mainly rated as limited can be explained by the fact that neither of the two curricula specifies learning outcomes in this area. This, however, runs contrary to the information provided by the interviewees on their understanding of entrepreneurship and the importance of such content, which suggests that knowledge in this area was regarded as important. Teachers are focussing on getting their students into employment: "In case one of the students is unemployed, he would call us and we would help them. We send a list with all students to companies with all the details of the students so that companies can contact them" (T1). Trainees who have not yet found a job are offered self-employment as an alternative:

We motivate them to start an own business if they don't get a job. We show them all possible ways they can go, how they can benefit from it, what support is available and how they can use the maximum of it to become a good entrepreneur (T7).

The teaching input for business and financial concepts and processes was also reported as low. This is particularly surprising given a large proportion of the curricula in the 'entrepreneurship' module relates to financial processes and the financial environment. Those who teach content in this area teach "knowledge about banks" (T4) or knowledge 
about "financial support you can get from the government, neighbours and parents" (T3).

Overall, it is clear that none of the knowledge categories reflected in the curriculum content is taught by all teachers. Only a few teachers cover the framework and processes connected with entrepreneurship (and those only to a limited extent). The focus is more on preparing trainees for employment and on tackling areas such as ethical values and the financial framework. This is not adequate reason for assuming that students are sufficiently familiar with the range of opportunities offered by differing forms of employment to recognise the possibilities.

\section{Attitudes}

The six main categories in the 'attitude' domain were 'ability to reflect' (A1), 'entrepreneurial identity' (A2), 'self-efficacy' (A3), 'pro-activeness' (also referred to as 'creativity') (A4), 'entrepreneurial passion' (A5) and 'perseverance' (A6). All competencies except 'entrepreneurial passion' were identified in the prescribed curriculum (Table 3).

The teachers attached highest value to 'self-efficacy' as a combination of 'self-awareness' and 'self-confidence' and to 'creativity'. These are also the only areas that all teachers said they taught. For all other entrepreneurial attitudes, only some interviewees said they developed their students' skills. Asked how they used teaching to contribute to students' self-efficacy, interviewees gave very diverse responses. One teacher saw monthly testing as a means towards strengthening self-efficacy. However, in terms of motivation research, this would be borne out only if it produced positive outcomes. Since this was not universally the case, we cannot reliably assume that there was teaching input in this case. All other teachers reported either that they motivated their students and encouraged them to have confidence in their own skills or to overcome their own weaknesses by giving them positive feedback and showing them ways of developing such attitudes, or that they set them practical exercises, such as presentations or conversations. "We teach self-efficacy in an overarching way: making them speak, help them to overcome their weaknesses, to give and receive feedback about strengths" (T3).

In the area of 'creativity', a total of seven respondents referred to practical methods, including role-play, work with case studies, use of multimedia, and work with projects and creativity tools. "We teach it wide-ranging, for example by giving them practical projects" (T4). Nevertheless, one interviewee stated: "They have to be born with that" (T4). In some cases, therefore, teachers assume that creativity cannot be taught.

As with 'creativity', there is an assumption here that 'initiative' cannot be taught or learned: "You need to have it. It's a basic nature. Nobody can teach it." (T6). The pictures drawn by the teachers regarding the 'ability to reflect' and 'perseverance' are the most heterogeneous. While in each case three teachers said that they spent little, if any, time teaching this ability to reflect, three said that they covered it in a wide-ranging way and two that they covered it comprehensively.

We teach self-reflection and problem-solving skills comprehensively. We make them speak, overcome their weaknesses and give feedback about their strengths. To enhance problem-solving skill we give them opportunities and situations to solve problems by their own. That could be real problems, for example if a machine is not working, or 
they have to solve problems during role plays (T3).

Overall, teaching input in the area of attitudes varies widely from one ITI to another. Many teachers were of the view that attitudes such as creativity, initiative and appetite for risk cannot actually be taught.

Skills

In the 'skills' domain only two out of four competencies were identified in the prescribed curricula (Table 4). The focus in the 'skills' domain was, therefore, on the areas of 'strategic skills' (S2) as well as 'interpersonal skills' (S4).

The highest assessment by teachers of their teaching input was in the area of 'interpersonal skills' and here especially in 'communication skills' and 'team-working skills', which reflects the marked focus on this areas in the curricula. Three teachers reported using interviews to teach communication skills, two use presentations and group discussions, and one uses role-play. One teacher involved industry partners, who conduct interviews with the students. One teacher commented on the problems of teaching such skills: "Students come from a zero English level. We have to make them speak English. So we let them read newspapers, prepare them for job interviews and teach them to speak in the class and during group discussions." (T3)

Teachers focus on the fact that the main priority is to equip students to speak English, since very few have any English language skills before joining the course.

'Team-working skills' are not formulated as a learning outcome in the curricula, but the 2011 curriculum describes teaching methods that enable this skill to be practised and developed. Five teachers describe group-work and a further three required students to work on projects in teams: "We give them projects and tasks they have to coordinate in a group" (T3) or in short "all what they do is in a team" (T6).

In this context, one teacher added: "We do a lot of projects in team-work. We do one activity each year in June. For example we do tree planting, cleaning, cutting and we go to the national safety day" (T5).

Respondents also cited activities that exceed what is written in the curriculum and are designed to promote team-working skills. Teaching and learning research demonstrates that the extent of cooperative learning by itself will not promote social competencies. The structuring of the interaction processes that take place during cooperation does, however, promote such social competencies (Edeling \& Pilz, 2016). It is, however, unclear how far the teachers interviewed actually structured interaction processes in group-work.

'Strategic skills' were implemented very rarely. Just two teachers reported that they implemented them in a wide range or comprehensively. Another two teach them little. Four don't teach these skills at all. The teachers who teach the skills said that these are achieved through projects carried out by the students. "Students have to manage projects and we counsel them during the process" (T7). There is no theoretical underpinning as described in the curriculum. 


\subsection{Interpretation of the Results}

The 'entrepreneurship' module is based on a narrow definition of entrepreneurship education that focuses primarily on teaching knowledge of how to set up and run a business. Scrutiny of the other modules in the 'employability skills' curriculum shows evidence of a broader definition of entrepreneurship education. Teachers' understandings are in line with the wide definition of entrepreneurship education and the broad 'employability skills' curriculum, and hence the prescribed curriculum.

The intensity with which the individual categories are delivered in practice varies widely, however. One reason for this is the unclear and rudimentary description contained within the curriculum. The elements included in the 'knowledge' dimension were mostly delivered as planned, but the enacted curriculum diverges from the prescribed and adopted one in the 'knowledge of career opportunities and of the world of work' category: all that is evident in both the curriculum and the teaching materials is the prospect of entrepreneurship/self-employment, with no content relating to paid employment. This is mirrored in interviewees' understanding in relation to curriculum content. In practice, however, the focus in teaching is on future employment in a company, with no proactive input on the prospect of entrepreneurial self-employment.

Teachers are aware of the elements of the 'skills' and 'attitudes' domains prescribed in the curriculum, which form part of their understanding of entrepreneurship education, but this understanding is seldom translated into teaching input or, if it is, is delivered relatively crudely. Some teachers justify this non-implementation by arguing that skills and attitudes cannot be taught and that they deliver other input, such as team-working skills, through group-work. Whether, and to what extent, the application of the social form is delivered in a structured and/or reflective way remains unclear.

In summary the findings show clearly, that even though the adopted is closely based on the prescribed curriculum, what lacks is the transformation into day-to-day teaching. Reasons seem to rely heavily on teachers perception that skills and attitudes can't be taught. Implications arising from those findings are therefore closely connected to teacher training, especially with regard to didactics and pedagogy tackling the teaching of softand personal-skills.

\section{Conclusion}

How is entrepreneurship education prescribed, adopted and enacted in Indian ITIs? Do the recently introduced curricula have the potential to enhance the entrepreneurship knowledge, skills and attitudes of ITI graduates in order to facilitate employment pathways - as an employee or self-employed? Within this study we tried to address those questions.

It can be concluded that the wide definition of entrepreneurship education underpins both the 'employability skills' curriculum and the teachers' understandings of entrepreneurship education. However, the findings also show that there are shortcomings in day-to-day teaching in some areas, particular as regards skills and attitudes. Many teachers have difficulty teaching these two domains. They rationalise these problems by citing inadequate equipment (in particular, machinery) and time. Both equipment and 
time influence delivery of the curriculum on a day-to-day basis (Posner, 2004). Other studies come to similar findings in the Indian context, both at ITIs and general secondary schools (Pilz et al., 2016; Tara et al., 2016)). With regard to soft skills and attitudes, teachers see delivery itself as their main problem (see also Ajithkumar, 2016). The personal influence that the teacher embodies (Posner, 2004) can be an obstacle here. Teachers appear to lack the methodological knowledge to teach soft skills and attitudes, so in-service training in specific teaching methods and the provision of appropriate teaching materials would be useful approaches. Even though their adopted curriculum includes the skills and attitudes, delivery in the day-to-day teaching falls short. Pilz et al. (2016) concluded for the Indian context that the focus in day-to-day teaching was on knowledge and marks, while underplaying skills and attitudes. Detailed curricula, teaching materials tailored to teaching skills and attitudes, and in-service training for teachers on appropriate teaching methods would contribute to better use of the potential for entrepreneurship education to facilitate students' transition from training to the labour market.

It became clear that the teachers working for the ITIs are strongly guided by what is specified in the curriculum and teaching materials. Guidelines must, therefore, be expressed clearly and in detail if entrepreneurship education is to develop both entrepreneurial and personal independence that is, the day-to-day teaching is to reflect the wider definition of entrepreneurship education. Reducing ambiguity would enable misunderstandings to be minimised and make it easier for teachers to implement the curriculum. It would also require teaching materials to be coordinated with curriculum content, demand adequate depth in the curriculum, and require the inclusion of specific suggestions for teaching, along with exercises and questions that ensure that lessons run smoothly.

It also became clear in the interviews that, in some areas, teachers place in their dayto-day teaching less emphasis on self-employment than on employment, even though their adopted curriculum included self-employment aspects. Entrepreneurship and selfemployment need to be highlighted more by teachers as an option for the post-vocational training period, so that students do not discount this option for earning their living. Instruction for the teachers could be very helpful in this context.

The findings of this study also point to the substantial gap that needs to be covered to make entrepreneurship education better aligned with VET in India. Based on a study of Sub-Saharan Africa, Sandirasegarane, Sutermaster, Gill, Volz, and Mehta (2016) point out the need to judiciously balance the distinctive strengths and weaknesses of the VET and entrepreneurship education, and deliver an integrated and context specific learning incorporating the practical and transferable skills. Based on a German study, Holtsch (2014) highlights the need to tailor the entrepreneurship training to differing levels of entrepreneurial intentions amongst the young students. Recognising that the perceived value of the entrepreneurship education may vary with entrepreneurial intent, Holtsch also notes that the knowledge of entrepreneurship itself can influence such intentions. It follows from the above research that the challenges of incorporating entrepreneurship training into the VET is complex and multi layered, and the curriculum design and the comprehension and ability of teachers to deliver that curriculum are important contributors to this end. 
These findings contribute a valuable basis for achieving the delivery intended by the government of its new entrepreneurship education curriculum as laid down in the National Policy on Skill Development and Entrepreneurship (GoI, 2015). Beside the measures announced in this National Policy, the design and implementation of an entrepreneurship curriculum at secondary or even primary level, which focus at the implementation level on the preparation for self-employment, could be useful. Most children dropping out of primary or secondary school (see section 2.2) enter the informal sector to help work at their relatives' businesses or even setting up a new business (see, e.g. Pilz, Uma, \& Venkatram, 2015; Pilz \& Wilmshöfer, 2015). Entrepreneurship education following the wide as well as narrow education has the potential to help those working in the informal sector as well as those working in the formal sector. But defining a curriculum is not sufficient the teaching quality and the processes used by the teachers are also important in enhancing student learning outcomes (Singh \& Sarkar, 2015). Considering the results of Pilz et al. (2016) for the Indian context, it becomes clear that the problems teachers perceive in implementing the prescribed curricula are similar in secondary schools as well as in ITIs, especially with regard to skills and attitudes. Some of the findings presented in this paper could be taken into consideration when developing curriculum, and especially in associated teacher training and in facilitating teaching-learning environments. 


\section{References}

Ajithkumar, M. U. (2016). Training of teachers: Institutionalising training and development of academic faculty of TVET institutions for realising excellence. In M. Pilz (Ed.), India: Preparation for the world of work: Education system and school to work transition (183-210). Wiesbaden: VS Verlag für Sozialwissenschaften.

Berger, S., Canning, R., Dolan, M., Kurek, S., Pilz, M., \& Rachwal, T. (2012). Curriculummaking in pre-vocational education in the lower secondary school: A regional comparative analysis within Europe. Journal of Curriculum Studies, 44(5), 679-701. Retrieved from: http://dx.doi.org/10.1080/00220272.20 12.702223

Bloomer, M. (1997). Curriculum making in post-16 education: The social conditions of studentship. London, New York: Routledge.

Bransford, J. D., Brown, A. L., \& Cocking, R. R. (2000). How people learn: Brain, mind, experience, and school. Washington, D.C.: National Academy Press.

Brewer, L. (2013). Enhancing youth employability: What? Why? and How? Guide to core work skills. Genever: International Labour Office, Skills and Employability Department.

Edeling, S. \& Pilz, M. (2016). Teaching self- and social competencies in the retail sector: Findings from vocational schools in Germany, Italy and Poland. Education and Training, 58(9). Online first, Retrieved from: http://dx.doi.org/10.110 8/ET07-2015-0060

Edwards, R., Miller, K., \& Priestley, M. (2009). Curriculum-making in school and college: The case of hospitality. The Curriculum Journal, 20(1), 27-42.

EURYDICE (2012). Entrepreneurship education at school in Europe: National strategies, curricula and learning outcomes. Brussels.

Federation of Indian Chambers of Commerce \& Industry (2012). Knowledge paper on skill development in India: Learner first. Retrieved from: https://imyriaads.fi les.wordpress.com/2013/02/ficci_skill_report_2012.pdf

Fisher, S. L., Graham, M. E., \& Compeau, M. (2008). Starting from scratch: Understanding the learning outcomes of undergraduate entrepreneurship education. In R. T. Harrison \& C. Leitch (Eds.), Entrepreneurial learning: Conceptual frameworks and applications (314-340), Routledge studies in entrepreneurship. London, New York: Routledge.

Fullan, M., \& Pomfret, A. (1977). Research on curriculum and instruction implementation. Review of Educational Research, 47(1), 335-397.

Gartner, W. B. (1990). What are we talking about when we talk about entrepreneurship? Journal of Business Venturing, 5(1), 15-28.

Government of India (2009). National skill development policy. National skill development agency - Government of India (GoI). Retrieved from: http://www.skillde velopment.gov.in/assets/images/NationalSkillDevelopment PolicyMar09.pdf

Government of India (2011). Syllabus for employability skills. Retrieved from: http://fi les.hostgator.co.in/hostgator178796/file/syllabusemployabilityskills.pdf

Government of India (2014a). Educational statistics at a glance. Retrieved from: http://mhrd.gov.in/educational-statistics-glance-2

Government of India (2014b). Employability skills. Government of India - Ministry of 
labour \& employment - Directorate general for employment \& training. Retrieved from: http://dget.nic.in/upload/539e732425075EmployabilitySkills-Final.pdf

Government of India (2014c). Statistics of school education 2011-12. Retrieved from: http://mhrd.gov.in/sites/upload_files/mhrd/files/statistics/SSE1112.pdf

Government of India (2015). National policy on skill development and entrepreneurship 2015. Ministry of skill development and entrepreneurship - Government of India (GoI). Retrieved from: http://www.skilldevelopment.gov.in/assets/images/Skill\% 20India/policy\%20booklet-\%20Final.pdf

Heinonen, J., \& Poikkijoki, S.-A. (2006). An entrepreneurial-directed approach to entrepreneurship education: mission impossible? Journal of Management Development, 25(1), 80-94.

Herrmann, B. L., Gauthier, J. F., Holtschke, D., Berman, R., \& Marmer, M. (2015). The Global Startup Ecosystem Ranking 2015. Retrieved from: https://s3-us-west2.amazonaws.com/compassco/The_Global_Startup_Ecosystem_Report_ 2015_v1.2.pdf

Holtsch, D. (2014). Entrepreneurial intentions in initial vocational education and training. In S. Weber, F. K. Oser, F. Achtenhagen, M. Fretschner, \& S. Trost (Eds.), Becoming an entrepreneur (139-160). Rotterdam: Sense Publishers.

Jiang, Y., \& Kleitman, S. (2015). Metacognition and motivation: Links between confidence, self-protection and self-enhancement. Learning and Individual Differences, 37, 222-230. http://dx.doi.org/10.1016/j.lindif.2014.11.025

King, K. (2007). Training in the informal sector of India: An Asian driver? Paper delivered at the National Conference on Approaching Inclusive Growth through Skills Development. New Delhi. Retrieved from: http://portal.unesco.org/geo graphy/en/files/7184/11746486235Kenneth_King.pdf/Kenneth+King.pdf

Kumar, K. (2016). ITIs/ITCs: Industrial training institutes / industrial training centres. In M. Pilz (Ed.), India: Preparation for the world of work: Education system and school to work transition (pp. 65-80). Wiesbaden: Springer.

Lackéus, M. (2014). An emotion based approach to assessing entrepreneurial education. The International Journal of Management Education, 12(3), 374-396.

Lackéus, M. (2015). Entrepreneurship in education: What, why, when, how. Entrepreneurship 360. Background Paper. Paris: OECD.

Mehrotra, S. K. (Ed.) (2014). India's skills challenge: Reforming vocational education and training to harness the demographic dividend. New Delhi: Oxford University Press.

Mehrotra, S. K., Kalaiyarasan, A., Kumra, N., \& Raman, K. R. (2015). Vocational training in India and the duality principle: A case for evidence-based reform. Prospects, 45(2), 259-273. doi: 10.1007/s11125-015-9358-x

Metcalfe, J. S. (2004). The entrepreneur and the style of modern economics. Journal of Evolutionary Economics, 14(2), 157-175. http://dx.doi.org/10.1007/s00191-0040210-3

Palmer, R., Wedgewood, R., Hayman, R., King, K., \& Thin, N. (2007). Educating out of poverty?: A synthesis report on Ghana, India, Kenya, Rwanda, Tanzania and South Africa (Researching the Issues 70). London.

Pilz, M. [Ed.] (2016). India: Preparation for the world of work - Education system and 
school to work transition. Wiesbaden: Springer VS.

Pilz, M., Krisanthan, B., Michalik, B., Zenner, L., \& Li, J. (2016). Learning for life and/or work - the status quo of pre-vocational education in India, China, Germany and the USA. Research in Comparative and International Education, 11(2), 117-134. doi: $10.1177 / 1745499916637173$

Pilz, M., Uma, G., \& Venkatram, R. (2015). Skills development in the informal sector in India: The case of street food vendors. International Review of Education, 61(2), 191-209. http://dx.doi.org/10.1007/s11159-015-9485-x

Pilz, M., \& Wilmshöfer, S. (2015). Formal, nonformal, and informal learning in rural India: The case of fishing families on the Chilika Lagoon. Prospects, 45(2), 231-243. doi:10.1007/s11125-015-9338-1

Posner, G. J. (2004). Analyzing the curriculum (3rd ed.). London: McGraw Hill.

Rao, K. S., Joshi, S., Mathur, A. K., \& Sahoo, B. K. (2014a). The vocational training system: An employer's perspective. In S. K. Mehrotra (Ed.), India's skills challenge: Reforming vocational education and training to harness the demographic dividend (200-222). New Delhi: Oxford University Press.

Rao, K. S., Sahoo, B. K., \& Ghosh, D. (2014b). The Indian vocational education and training system: An overview. In S. K. Mehrotra (Ed.), India's skills challenge: Reforming vocational education and training to harness the demographic dividend (37-85). New Delhi: Oxford University Press.

Sandirasegarane, S., Sutermaster, S., Gill, A., Volz, J., \& Mehta, K. (2016). Contextdriven entrepreneurial education in vocational schools. International Journal for Research in Vocational Education and Training, 3(2), 106-126. http://dx.doi.org/10.1 3152/IJRVET.3.2.3

Schreier, M. (2012). Qualitative content analysis in practice. Thousand Oaks, California: SAGE Publications.

Shane, S., \& Venkataraman, S. (2000). The promise of entrepreneurship as a field of research. The Academy of Management Review, 25(1), 217-226.

Singh, R., \& Sarkar, S. (2015). Does teaching quality matter?: Students learning outcome related to teaching quality in public and private primary schools in India. International Journal of Educational Development, 41, 153-163. doi: 10.1016/j.ijedudev.2 015.02 .009

Stevenson, H. H., \& Jarillo, J. C. (1990). A paradigm of entrepreneurship: Entrepreneurial management. Strategic Management Journal, 11(5), 17-27.

Tara, N., Kumar, S., \& Pilz, M. (2016). Quality of VET in India: The case of industrial training institutes. TVET@Asia, 7, 1-17. Retrieved from: http://www.tvetonline.asia/issue/7/tara-etal

World Bank (2008). Skill development in India: The vocational education and training system. Washington DC: The World Bank.

Wragg, E. C. (2012). An introduction to classroom observation (3rd ed.). Oxon: Routledge. 


\section{Bibliographical Note}

Lea Zenner is research assistant at the Chair of Business and Economic Education and Training at the University of Cologne, Germany. Her research interests focus on international comparative vocational education research with a special focus on India, UK and US as well as school-to-work transition research.

Dr Kothandaraman Kumar is professor at the Apeejay Surrendra Chair Professor of Family Business and Entrepreneurship, Indian Institute of Management Bangalore, India. His research interests are in the areas of entrepreneurial strategies, high-growth entrepreneurship in emerging economies and family business management.

Dr Matthias Pilz is professor at the Chair of Business and Economic Education and Training and Director of the German Research Center for Comparative Vocational Education and Training (G.R.E.A.T.) at the University of Cologne, Germany. His research interests focus on comparative vocational education research and learning and teaching research.

We thank Ms. MSc. Christiane Hirsch for implementation of her field research results from India into the study. 